\title{
International Migration and Home Country Politics
}

\author{
Covadonga Meseguer • Katrina Burgess
}

Published online: 13 February 2014

(C) Springer Science+Business Media New York 2014

According to recent research, 215 million people - approximately 3\% of the world's population-live in a different country from that of their birth. Population flows take place notably from the developing South to the developed North, although a considerable volume of migration is of the South-South type (Ratha and Shaw 2007; Castles and Miller 2009; World Bank 2011). These movements of people are accompanied by financial, social, and political remittances sent by migrants to their countries of origin. In many developing countries, financial remittances have become a crucial source of foreign exchange and a potential tool for development. In 2010, remittance flows to developing countries were estimated to have exceeded $\$ 325$ billion, surpassing the inflows of foreign aid and, in some cases, foreign direct investment (World Bank 2006, 2011). Migrants also transfer knowledge, ideas, values, and expectations acquired in the host country back to their communities of origin in the form of social and political remittances (Levitt 2001; Piper 2009). Undoubtedly, together with the movement of goods, investment, capital, and information, international migration is a central component of globalization.

Whereas most research to date has emphasized either the economic consequences of international migration or its political impact in immigrant-receiving rather than emigrantsending countries, an increasing number of scholars are exploring a question surprisingly overlooked to date: what are the political consequences of migration and remittances for the migrants' countries of origin? And, more generally, what is the relationship between outmigration and the functioning of democracies in sending countries?

This special issue is one of the few collective efforts to date exploring the relationship between outmigration and politics, particularly in new democracies (see also Øestergaard-Nielsen 2003a; Lyons and Mandaville 2012). Specifically, the papers investigate whether and how emigrants and the remittances they send back home affect

C. Meseguer ( $\square)$

London School of Economics, Houghton Street, London WC2 2AE, UK

e-mail: covadonga.meseguer@gmail.com

C. Meseguer

Center for Research and Teaching in Economics, Santa Fe, Mexico

K. Burgess

Fletcher School, Tufts University, Medford, MA 02155, USA

e-mail: katrina.burgess@tufts.edu 
politics in their homelands; whether, in turn, politics is a factor affecting individual decisions to emigrate; and whether the transnational activities in which emigrants engage have any impact on the welfare of their communities. Building on the sporadic but increasing number of published contributions to the topic in political science, the collection encourages a dialog between two well-established but largely separate literatures: (1) work by sociologists and anthropologists on outmigration and transnationalism (see for instance Levitt 1998, 2001; Portes et al. 1999; Goldring 2002; Guarnizo et al. 2003; Østergaard-Nielsen 2003b; Smith 2003; Fox 2005; Waldinger 2008; Waldinger et al. 2008); and (2) work by political scientists on the quality of democracy and governance in new democracies (see for instance Schedler 1998; Agüero and Stark 1998; Przeworski et al. 1999; Mainwaring and Welna 2003; O'Donnell 2004; Diamond and Morlino 2005; Hagopian and Mainwaring 2005; Kitschelt and Wilkinson 2007). In the process, it contributes to a broader effort to build a coherent corpus of theoretical knowledge about the relationships between migration, remittances, and key aspects of democracy such as electoral and nonelectoral participation, political accountability, and representation.

\section{Channels of Migrant Influence on Home Country Politics}

The political consequences of emigration and remittances for sending countries have only recently become an subject of research. Relying on previous work by sociologists and anthropologists and on improved data on migrant flows and remittances, political scientists are beginning to explore how patterns of migrant transnationalism affect the political attitudes and behaviors in home countries. Extensive case-study research has shown that emigrants actively engage in the politics of their home countries (see e.g., Levitt 1998; Calderón-Chelius 2003; Lyons and Mandaville 2012). But what are the different channels through which outmigration and the expectation of outmigration influence political behavior? Does outmigration affect the patterns of political disengagement, political apathy, poor accountability, and clientelism that are pervasive in new democracies? For example, does contact with emigrant relatives and/or returnees - who are often exposed to democratic practices in their destination countries - shape and change the political behavior and attitudes in home countries? Does the receipt of remittances encourage electoral participation, or does it, to the contrary, demobilize individuals by making them less dependent on the state?

In this volume, we look into how outmigration and remittances affect patterns of indirect and direct political influence. Indirect political influence is triggered by remittances and regular communication with non-migrants back home. Financial remittances (individual and collective - sent by organized migrants abroad) may reshape the political incentives of non-migrants by making them less dependent on the state and by transforming migrants and their families into local public good providers. Regular communication between migrants and non-migrants may be a potential source of social remittances, that is, of "ideas, behaviors, identities, and social capital that flow from receiving to sending country communities" (Levitt, 1998: 927). Social remittances have the potential to change political attitudes and behaviors back home.

Direct political influence includes a wide repertoire of electoral and non-electoral activities such as (1) supporting candidates, parties, or policies; (2) making financial 
contributions to political campaigns; (3) mobilizing for and/or exercising expatriate political rights; and (4) leveraging remittances to induce local governments to invest in public goods and/or alter their style of governance. Most of the papers in this volume explore the impact of different types of remittances (individual, collective, social, and political) on a few direct and indirect political outcomes, providing insights about the conditions under which that impact is positive or not.

To explore these issues, the contributors to this volume rely on the channels by which emigrants and their remittances influence the politics of sending countries as identified by Kapur (2010). First, the prospect channel refers to how expectations of future migration may shape the current behavior of local residents. While some potential migrants may become politically disengaged (Bravo 2009), others may demand services that prepare them to compete in foreign labor markets.

Second, Kapur identifies the absence channel, whereby local political outcomes are altered by the departure of certain members of the community. If a society loses its most politically efficacious and critical members (political brain drain), migration is likely to depress domestic demands for political openness and accountability (Goodman and Hiskey 2008; Hiskey et al., this volume). By the same token, the departure of an entrenched elite may open up political space for new groups, a phenomenon that Kapur identifies as enabling India's democracy to adapt to profound social changes. ${ }^{1}$

Third, the return channel has to do with the impact of migrants returning home with different endowments of human and financial capital, as well as new ideas and access to new networks. In this case, the positive or negative effect that returnees have on their communities may depend on whether their return is voluntary or forced. In the latter case, returnees may be stigmatized as those who "did not make it" and, therefore, be disempowered.

Fourth and finally, the diaspora channel consists of emigrants exercising influence from abroad. ${ }^{2}$ This influence may include lobbying home governments, financing homeland elections (Nyblade and O'Mahony, this volume), or getting involved in local community development through public goods provision (Adida and Girod 2011; Aparicio and Meseguer 2012; Meseguer and Aparicio 2012; Duquette, this volume). In some cases, these activities may crowd out domestic claims to representation, embolden leaders or policies that perpetuate corrupt and/or exclusionary practices, or exacerbate ethnic, religious, or partisan cleavages. In others, they may encourage electoral competition, expand the political franchise, empower local residents to demand their rights, and hold politicians accountable in their communities of origin.

\footnotetext{
${ }^{1}$ Bearce and Hutnick (2011) reach a similar conclusion but with very different class dynamics. Rather than finding that democratization is enhanced by the departure of elites, they show that, to the extent that international migrants tend to be poor, emigration has a positive effect on political liberalization in sending countries by decreasing the amount of redistribution that would occur in a more democratic regime.

${ }^{2}$ As Brubaker (2005) notes, the term "diaspora" has been stretched beyond a few cases of dispossessed peoples with strong attachments to a conceptual homeland (e.g., Jews, Armenians) to include nearly any emigrant group. We agree with his argument that use of the term should be restricted to groups that meet the three criteria: (1) dispersion in space; (2) orientation to a 'homeland' as an authoritative source of value, identity, and loyalty; and (3) preservation a distinct identity within the host society (Brubaker 2005, 5-6). Thus, while we generally prefer the term "migrants" or "emigrants" to describe the people we are studying, we use Kapur's concept of the "diaspora channel" to capture episodes of engagement that meet these criteria (see, also, Lainer-Vos 2010).
} 
Thanks to new cross-national and survey data, scholars are now beginning to complement case studies of the aforementioned channels with systematic analysis of their impact on political engagement, local governance, and community welfare. We review this research next.

\section{Indirect Migrant Influence on Political Engagement Back Home}

There is a growing literature on the indirect influence of migrants on political engagement back home through the transfer of financial and/or social remittances. Specifically, scholars have explored the impact of migration and remittances on five key outcomes: voter turn-out, political partisanship, membership in civic organizations, non-electoral mechanisms of accountability, and attitudes toward democracy.

With regard to voter turn-out, existing studies suggest different effects depending on which channel is being activated, and where the migrants live or have lived. Chauvet and Mercier (2011) focus on the return channel and find that communities in Mali with a higher share of return migrants had higher rates of participation in the 1999, 2002, and 2004 local and national elections. Interestingly, they find that this effect is primarily attributable to migrants returning from African countries in the midst of a political transition rather than those returning from an advanced democracy.

The results for voter turn-out are less sanguine when we turn to the other three channels. Several studies suggest that economic and social remittances have, at best, no effect and, at worst, a harmful impact on electoral participation among non-migrants (Bravo 2009; González-Acosta 2008; Goodman and Hiskey 2008; Hiskey and Córdova 2012a, b; Krilova 2009). Goodman and Hiskey attribute electoral disengagement to "a combination of political brain drain and reorientation toward their emergent transnational community" (2008: 176). Bravo offers a moral hazard explanation: "remittances may break — or at least weaken - the link between the recipient's household welfare and the quality of governance (especially at the local level), thereby reducing the incentives to be involved in political affairs" (2009: 280). ${ }^{3}$ Taken together, these studies suggest that, rather than leading to higher turnout because of either improved socioeconomic status or the adoption of more democratic values, economic and social remittances may "free" non-migrants to exit from a political system toward which they feel even less loyalty after interacting with their migrant relatives.

Concerning partisanship, several studies suggest that remittances undermine the hold of dominant parties on the electorate. Using survey data for 18 Latin American countries and looking into the Dominican Republic case, Ahmed (2011) shows that, conditional on dissatisfaction with the ruling government, remittance recipients are $3 \%$ less likely to vote for incumbents. Likewise, in the case of Mexico, Pfutze (2010) finds a strongly positive relationship between average remittances per household and electoral support for opposition candidates at the local level, particularly in municipalities that had been governed continuously by the dominant Party of the Institutionalized

\footnotetext{
${ }^{3}$ Abdih et al. (2012) make a similar argument to explain a negative relationship between remittances as a share of GDP and control of corruption across 111 countries, arguing that "[r]emittances, acting as a buffer between the government and its citizens, give rise to a moral hazard problem; these flows allow households to purchase the public good rather than rely solely on the government to provide that good, which reduces the household's incentive to hold the government accountable" (2012: 664).
} 
Revolution (PRI). ${ }^{4} \mathrm{He}$ attributes this democratizing impact to the PRI's reduced capacity to use political patronage to remain in power. In other words, the same liberating effect of economic remittances that appears to create a moral hazard problem may also reduce the risk to non-migrants of challenging the status quo when they do participate in elections.

In the Dominican case, Morgan et al. (2011) reach a more troublesome conclusion regarding partisanship among remittance recipients. On the one hand, they find that recipients are much more likely than non-recipients to be affiliated with one of the two dominant parties, thereby indicating higher levels of engagement with the formal political system. This result supports their hypothesis that remittance income is not a "civic" substitute for engagement in politics as in Mexico or El Salvador, in part because remittance households in the Dominican Republic are more likely to be located in urban centers with well-developed political networks. ${ }^{5}$ On the other hand, they worry that this outcome reflects the successful integration of remittance households (and their migrant relatives) into clientelistic party networks, which would not bode well for the quality of democracy.

The results are more encouraging when we turn to non-electoral forms of political participation, particularly membership in civic organizations. Goodman and Hiskey (2008), González-Acosta (2008), Pérez-Armendáriz and Crow (2010), and Hiskey and Córdova (2012a, b) all find that economic remittances and/or migrant ties are positively associated with organizational membership. ${ }^{6}$ This finding is especially notable because of its consistency across different methods and countries. Although higher levels of civic engagement can coexist with — and perhaps even reinforce-withdrawal from the formal political system in the short term, they may strengthen democracy in the long term by building social capital and collective capacity, thereby laying a foundation for political mobilization in the future.

There is also some evidence that economic and/or social remittances encourage nonmigrants to demand more accountability from public officials, although the results are mixed. On the positive side, Hiskey and Córdova (2012a, b) find that individuals in the six countries in their study who receive remittances and/or have migrant ties are more likely to have interacted with local authorities. In the Mexican case, Pérez-Armendáriz and Crow (2010) find that individuals with migrant ties are more likely to have contacted public officials or the media, supported political campaigns, and/or engaged in protest. ${ }^{7}$ Using household survey data and a voting experiment in Cape Verde, Batista and Vicente (2011) find that migrant households are more likely to demand accountability by public officials, particularly if their relatives are in the USA (compared to Portugal). ${ }^{8}$ On the negative side, Goodman and Hiskey (2008) find that Mexicans with migrant ties are less likely to engage in a broad range of non-electoral

\footnotetext{
${ }^{4}$ In a related study, Pfutze (2010) finds that migrant households contributed to Mexico's transition away from a hegemonic-party system between 2000 and 2002. See also Díaz-Cayeros et al. (2003).

${ }^{5}$ In contrast to Mexico, they also find a strong relationship between partisan activity and civic engagement.

${ }^{6}$ Unlike the other authors, Pérez-Armendáriz and Crow (2010) find no statistically significant relationship between remittances and participation in civic organizations in Mexico.

7 They found no statistically significant relationship between these activities and economic remittances, however.

${ }^{8}$ The experiment consisted of asking respondents to a survey on perceived corruption in public services to mail a pre-stamped postcard if they wanted the aggregate survey results to be made publicly available in the media (2009: 3).
} 
activities necessary to hold politicians accountable, a pattern that Bravo (2009) replicates with regard to their propensity to engage in political conversation.

One final strand of research concerns attitudes toward democracy. The negative impact of financial and social remittances on political engagement receives further support from studies that incorporate attitudes about democracy. In Mexico, individuals with ties to migrants appear more likely to believe that democracy is the best system (Hiskey and Córdova 2012a, b), but they are also more likely to be dissatisfied with democracy in their own country (Bravo 2009; Pérez-Armendáriz and Crow 2010). Hiskey and Córdova (2012a, b) find similar outcomes with regard to remittances across the six countries in their study. ${ }^{9}$ In the Dominican case, González-Acosta (2008) does not find any statistically significant difference between remittance recipients and nonrecipients regarding the value of democracy or how it functions in their country, but he does find that recipients are less likely to trust key public institutions. Finally, Chauvet and Mercier (2011) find that communities in Mali with higher shares of returnees, particularly from non-African countries, have a lower preference for democracy, are less interested in politics, and have a greater distrust of Mali's political system.

In sum, these results point to mostly negative or ambivalent results concerning electoral participation and attitudes toward democracy as a result of outmigration and the reception of remittances. However, non-migrants with connections abroad seem to turn to alternative forms of non-electoral political engagement, with positive implications for the quality of democracy.

\section{Migration, Remittances, and Welfare}

There is a complementary literature on the politics of migrant-financed welfare provision in high-migration communities. Using evidence from Mexican municipalities, Adida and Girod (2011) show that remittances empower households that receive them to invest in public utilities (drainage and water). ${ }^{10}$ Migrants loom as important non-state providers of public goods, especially in decentralized political settings (Grindle 2007). A different version of migrant involvement consists of public-private partnerships in which migrant organizations commit collective remittances to provide public and social infrastructure in their communities of origin. Often, these organizations take the form of hometown associations (HTAs), which are voluntary associations in destination countries of immigrants with a common place of origin. Through membership fees and other activities, these associations raise money (collective remittances) to invest in their localities (Guarnizo et al. 2003; Orozco 2003; Burgess 2005; Fox and Bada 2008; Iskander 2010; Duquette, this volume).

As with the research on the impact of outmigration on political behavior and attitudes, extant research is ambivalent about the impact of hometown associations on local accountability and local development. Anecdotal evidence abounds showing that HTAs involved in their communities are capable of demanding more transparency

\footnotetext{
${ }^{9}$ In the Mexican case, Pérez-Armendáriz and Crow (2010) find no statistically significant relationship between remittances and satisfaction with democracy.

${ }^{10}$ While pointing to the contribution that remittances can make to household welfare, however, their findings also support the moral hazard argument discussed above.
} 
and higher standards of public good delivery. Much of this evidence is based on the well-researched Mexican case (Espinosa 1999; Orozco 2003; Fernández de Castro et al. 2006; Lanly and Valenzuela 2004). The same positive outcome has been reported in other high-outmigration countries such as El Salvador, the Dominican Republic, Mali, or the Philippines (Burgess 2011). In these accounts, migrants working with their communities led to enhanced participation, better accountability, more transparency, and less corruption.

Yet, this anecdotal evidence is far from capturing the whole story. Numerous studies report failed public-private partnerships with migrant participation. This participation is often fraught with conflicts with community residents or local politicians and subject to similar clientelistic exchanges to those they are supposed to ameliorate (Burgess 2005; Shannon 2006; Fox and Bada 2008; Duquette 2010). In particular, when partnerships involve municipal or superior levels of government, the assignment of public goods suffers from political biases and is the object of political manipulation, too. In two recent articles, Aparicio and Meseguer (2012) and Meseguer and Aparicio (2012) show that public goods allocation under the Mexican Three for One Program (a paradigmatic and emblematic case of a public-private partnership involving HTAs) followed patterns that favored the strongholds of the ruling National Action Party (PAN) in states and municipalities of this party label. Therefore, although homelands may be better off thanks to the active involvement of migrants (Duquette, this volume), their impact on better accountability is not unconditional (Burgess 2011). Also, the targeting of matching grants as a poverty reduction tool is questionable (Aparicio and Meseguer 2012).

\section{Answers and Further Questions}

The contributions to this volume build on these two literatures and constitute a good example of the diversity of issues on the agenda, the variety of mechanisms that the extant literature has already identified, and the different empirical strategies to tackle them. Burgess, Nyblade and O'Mahony, and Pérez-Armendáriz study the direct and indirect impact of outmigration on several individual and aggregate political behaviors. They probe the diaspora and the return channels. Hiskey and his co-authors reverse the question and explore the extent to which the perceived functioning of the political system in the country of origin is a determinant of individual emigration decisions. In other words, they test for a reverse prospect channel whereby frustration with certain aspects of unconsolidated democracies may lead individuals to consider leaving. Finally, Duquette explores another aspect of the diaspora channel. In particular, she examines whether public-private partnerships involving HTAs have a positive impact on the welfare of outmigration communities, in particular, poor ones.

Three papers address these issues in comparative perspective (Burgess, Nyblade and O'Mahony, and Hiskey et al.), whereas two papers use Mexico as a case study (PérezArmendáriz and Duquette). The over-representation of Mexico in current research should come as no surprise. First, given the volume, long tradition, and concentration of Mexican migration to the USA (more developed and with better governance indicators), the Mexican case offers an unbeatable laboratory to study the domestic impact of outmigration. And second, some of the alleged channels of migrant influence exist at the local level and require local data to be explored. These data are readily 
available and of high quality in Mexico. In any case, all the contributions to this volume are engaged in crucial debates in comparative politics. And those authors who offer case-study evidence are careful to present it in comparative perspective. Despite the regional focus, we think that the papers' questions and methods can be of relevance for the study of outmigration and politics in new democracies outside Latin America.

Burgess asks a question that, indeed, should precede any research on the political consequences (good or bad) of outmigration. Surprisingly, this preliminary question has not yet been answered in a systematic way: under what conditions are migrants likely to activate the diaspora channel of political influence? To this end, the author constructs a scoring system to identify the expected level of migrant engagement in homeland politics in "new democracies" in the developing world. Specifically, she is interested in three types of political activity by migrants: (1) electoral participation in the form of expatriate voting or campaign financing; (2) issue advocacy through individual or collective lobbying of home governments; and (3) philanthropy directed at financing public goods in the migrants' communities of origin. Although she is still gathering data to measure these outcomes, she lays the empirical groundwork by proposing and coding two sets of likely determinants. The first set of determinants includes socioeconomic incentives generated by cross-border linkages and migrant profiles (e.g., gender, education, destination) likely to predispose them toward broader forms of transnational engagement. The second set of determinants includes political incentives generated by diaspora politicization and formal access to the political process in the home country. After scoring each set of incentives in 40 countries, she plots them in a series of matrices designed to capture the interaction between them. In the process, she generates testable hypotheses about the conditions under which migrants are likely to activate the diaspora channel, as well as the form such activation is likely to take.

Nyblade and O'Mahony help us understand one particular aspect of the diaspora channel: migrant involvement in home country elections. In particular, the authors explore the conditions influencing remittance cycles in which migrants send more money home in election years. The authors refer to these flows as "political remittances." O'Mahony (2013) uses cross-national annual remittance data to show that migrants' remittances increase in election years, an effect that is larger the more contested the election and the poorer the home country. This paper not only provides more nuanced statistical analysis of cross-national remittance flows using newly available monthly and quarterly cross-national remittance data for primarily Latin American countries, but also demonstrates the existence of sub-national political remittance cycles around Mexican gubernatorial elections. Given that migrants' loyalty to their homelands is often local rather than national, demonstrating the existence of sub-national political remittance cycles provides key evidence of an important mechanism for diaspora channel influence. The hypothesis the authors probe is that migrants send more money home in election years and when local elections are more contested, probably expecting that their resources will be decisive in tilting the balance in favor of a particular party.

Pérez-Armendáriz throws light on the under-explored return channel. Recall that one of the possible ways in which outmigration is hypothesized to affect the political behavior of those left behind is through "trans-state conversation", that is, through the information, resources, different values, and ideas (social remittances) that migrants communicate from abroad or bring with them when they return home. Pérez- 
Armendáriz compares the impact of these two groups on the political beliefs and behavior of non-migrants. Based on 150 interviews of Mexican emigrants, she concludes that non-migrants are more receptive to the behaviors and beliefs they learn about from émigrés abroad than from returning migrants. The difference holds even when the norms, knowledge, practices, and ideas that émigrés and returning migrants learn and share with non-migrants are highly similar. This is because with return migration, the prospect and absence channels of migrant influence become less relevant, whereas émigrés keep both channels open for those left behind.

Hiskey et al. reverse the direction of causality to inquire instead whether in Latin America, the quality of democracy is a determinant of individual intentions to emigrate. Besides showing that the relationship between the quality of democracy and outmigration runs both ways, this paper speaks to the mammoth literature exploring the sociological and economic determinants of decisions to emigrate (see for instance Massey et al. 1998). This literature has generally ignored the possibility that political disillusionment with the functioning of democracy may also be a determinant of outmigration. Using survey data from 22 Latin American countries and a multi-level approach, the authors examine whether levels of corruption, crime victimization, and overall satisfaction and experience with democracy enter into the constellation of reasons leading individuals to consider outmigration as a life option. It is indeed the case that they do.

Finally, Duquette enhances our knowledge about the workings of one aspect of the diaspora channel. The author asks a straightforward question: does co-production of public works by migrants and public agencies improve citizens' access to social welfare? In particular, Duquette looks into the provision of several public goods and poverty reduction under the Three-for-One Program, a matching grant scheme whereby municipal, state, and federal administrations multiply by three the collective remittances that migrant clubs abroad send to their communities (Burgess 2005; Fernández de Castro et al. 2006; Iskander 2010; Aparicio and Meseguer 2012; Meseguer and Aparicio, 2012). This program was born in the state of Zacatecas in the 1980s and became federal in 2002. To date, it is second only to Mexico's conditional cash transfer program, Oportunidades, in terms of the total anti-poverty budget. Using municipal data for the period 2002-2008, Duquette finds that the program improves the provision of sewage and drainage and contributes to poverty reduction in Mexican municipalities. The author also finds that collective and individual remittances substitute each other: in the presence of transnational coproduction, migrant households are less likely to improve public goods using family remittance resources, but in the absence of Threefor-One Program participation, migrant households continue to improve their hometowns with individual remittances. This finding is relevant for frequently poorly financed Mexican municipalities and of interest to other countries that might employ this kind of co-production scheme.

In sum, comparativists interested in how outmigration (a central feature of globalization) may have an impact on electoral and non-electoral participation and development in new democracies will find in this special issue an excellent sample of current research questions and empirical strategies to address them. Roughly speaking, in this issue, we learn that a poor quality of democracy induces individuals to emigrate; yet, this does not mean that they disengage from local politics and from the welfare of their communities. How much they engage depends on a host of demographic and 
institutional factors, with high levels of outmigration being just part of the story. We also learn that migrants are more likely to exert an influence while they remain abroad. However, this influence wanes when they return.

Of course, this special issue leaves us with more questions than it answers, specifically about alternative micro mechanisms by which the absent, return, prospect, and diaspora channels operate and produce positive but also negative results. Also, the contributions focus on just a few political outcomes, admittedly leaving outside their scope other important informal expressions of participation. But to the extent that these contributions probe different aspects of the above channels, this special issue is a valuable contribution to our understanding of the relationship between international migration and home country politics in new democracies.

Acknowledgment The editors acknowledge the support of the MacArthur Foundation, which allowed us to organize the Workshop "Politics and Migration in Out-Migration Countries" at CIDE, Mexico City, in September 2011, where initial versions of the papers were discussed. We are grateful to two anonymous reviewers for their helpful comments and suggestions.

\section{References}

Abdih Y, Chami R, Dagher J, Montiel P. Remittances and institutions: are remittances a curse? World Dev. 2012;40(4):657-66.

Adida CL, Girod DM. Do migrants improve their hometowns? Remittances and access to public services in Mexico, 1995-2000. Comp Polit Stud. 2011;44(1):3-27.

Agüero F, Stark J, editors. Fault lines of democracy in post-transition Latin America. Miami: North-South Center Press/University of Miami; 1998.

Ahmed FZ. Remittances, clientelism, and electoral dynamics. Working paper, 2011. Oxford University.

Aparicio J, Meseguer C. Remittances and the state: the $3 \times 1$ program in Mexican municipalities. World Dev. 2012;40(1):206-22.

Batista C, Vicente P. "Do migrants improve governance at home? Evidence from a voting experiment." World Bank Economic Review, Oxford University Press, vol. 25(1), pages 77-104. 2011.

Bearce D, Hutnick J. "International labor mobility and domestic political liberalization". Paper presented for discussion in the Annual Meeting of the American Political Science Association, Seattle, WA. 2011.

Bravo J. "Emigración y compromiso político en México." Política y gobierno, Volumen temático: Elecciones en México. 2009. 273-310.

Brubaker R. The 'diaspora' diaspora. Ethnic Racial Stud. 2005;28(1):1-19.

Burgess K. Migrant philanthropy and local governance in Mexico. In: Merz B, editor. New patterns for Mexico: remittances, philanthropic giving, and equitable development, vol. 10. Cambridge: Harvard University Press; 2005.

Burgess K. "Migration and accountability in new democracies. Mexico's $3 \times 1$ program in comparative perspective". Unpublished manuscript. 2011.

Calderón Chelius L. Votar en la distancia. La extensión de los derechos políticos a migrantes, experiencias comparadas. Mexico: Instituto Mora and Coordinacion General para la atencion al migrante Michoacano; 2003.

Castles S, Miller MJ. The Age of Migration. 4th ed. New York: Palgrave USA; 2009.

Chauvet L, Mercier M. "Migration and elections in Mali. Does migration promote democratization in Africa?" Preliminary draft, presented at CSAE 25th Anniversary Conference 2011. Economic Development in Africa. 2011.

Diamond LJ, Morlino L. Assessing the quality of democracy. Baltimore: Johns Hopkins University Press; 2005.

Díaz-Cayeros A, Magaloni B, Weingast BR. Tragic brilliance: equilibrium hegemony and democratization in Mexico. Working paper, Stanford University. 2003.

Duquette L. Explaining migrant-state coproduction: emergence, structural forms and impact." Paper presented at workshop on "Immigrants and their homelands: engagements, impacts, responses". Los Angeles: UCLA Migration Studies Group; 2010. 
Espinosa V. The Federation of Michoacán Clubs in Illinois. Illinois: Report commissioned by Heartland Alliance for Human Needs and Human Rights; 1999.

Fernández de Castro R, García Zamora R, Vila Freyer A (eds). El Programa $3 \times 1$ para migrantes. ¿Primera política transnacional en México? Mexico: ITAM, Miguel Angel Porrúa, Universidad de Zacatecas. 2006.

Fox J. Unpacking ‘transnational citizenship'. Ann Rev Polit Sci. 2005;8:171-201.

Fox J, Bada X. Migrant organization and hometown impacts in rural Mexico. J Agrar Chang. 2008;8(2-3): 435-61.

Goldring L. The Mexican state and transmigrant organizations: negotiating the boundaries of membership and participation. Lat Am Res Rev. 2002;37(3):55-99.

González Acosta E. "Migrant money, political implications: remittances, exit, voice, and loyalty in the Dominican Republic: Research Plan.” Unpublished Ms. 2008.

Goodman GL, Hiskey J. Exit without leaving: political disengagement in high migration municipalities in Mexico. Comp Polit. 2008;40(2):169-88.

Grindle MS. Going local: decentralization, democratization, and the promise of good governance. Princeton: Princeton University Press; 2007.

Guarnizo LE, Portes A, Haller W. Assimilation and transnationalism: determinants of transnational political action among contemporary migrants. Am J Sociol. 2003;108:1211-48.

Hagopian F, Mainwaring S. The third wave of democratization in Latin America: advances and setbacks. New York: Cambridge University Press; 2005.

Hiskey J, Córdova A. Measuring migration connections across Latin America. In: Cuécuecha A, editor. Migration and remittances: trends, impacts and new challenges. Maryland: Lexington Books; 2012a. p. 165-85.

Hiskey J, Córdova A. Measuring migration connections across Latin America. In: Alfredo C, Carla P, editors. Migration and remittances from Mexico: trends, impacts, and new challenges. Lanham, MD: Lexington Books; 2012b. p. 165-86.

Iskander N. Creative state: forty years of migration and development policy in Morocco and Mexico. Ithaca: Cornell University Press; 2010.

Kapur D. Diaspora, development, and democracy: the domestic impact of international migration from India. Princeton: Princeton University Press; 2010.

Kitschelt H, Wilkinson S. Patrons, clients, and policies: patterns of democratic accountability and political competition. New York: Cambridge University Press; 2007.

Krilova N. Political effects of remittances: political participation in developing countries, $\mathrm{PhD}$ Thesis. Creighton University. 2009.

Lainer-Vos D. Diaspora-homeland relations as a framework to examine nation-building processes. Sociol Comp. 2010;4(10):894-908.

Lanly G, Valenzuela MB (eds). Clubes de Migrantes Oriundos Mexicanos en los Estados Unidos. Universidad de Guadalajara. 2004.

Levitt P. Social remittances: migration driven local-level forms of cultural diffusion. Int Migr Rev. 1998;32(4): 926-48.

Levitt P. The transnational villagers. Berkeley: University of California Press; 2001.

Lyons P, Mandaville T, editors. Politics from afar: transnational diasporas and networks. New York: Columbia University Press; 2012.

Mainwaring S, Welna C, editors. Democratic accountability in Latin America. Oxford: Oxford University Press; 2003.

Massey D, Arango J, Hugo G, Kouacouci A, Pellegrino A, Edward Taylor J. Worlds in motion: understanding international migration at the end of the millennium. Oxford: Clarendon Press; 1998.

Meseguer C, Aparicio J. Supply or demand? Migration and political manipulation in Mexico. Stud Comp Int Dev. 2012;47(4):411-40.

Morgan J, Harthtlyn J, Espinal R. Dominican party system continuity amid regional transformations: economic policy, clientelism, and migration flows. Latin Am Polit Soc. 2011;53(1):1-32.

O'Donnell G. Why the rule of law matters. J Democr. 2004;15(4):32-46.

O’Mahony A. Political investment. Remittances and elections. Br J Polit Sci. 2013;43(4):799-820.

Orozco M. Hometown associations and their present and future partnerships: new development opportunities? Washington: USAID; 2003.

Østergaard-Nielsen E, editor. International migration and sending countries. London: Palgrave MacMillan; 2003a.

Østergaard-Nielsen E. The politics of migrants' transnational political practices. Int Migr Rev. 2003b;37:760-86.

Pérez-Armendáriz C, Crow D. Do migrants remit democracy? International migration, political beliefs, and behavior in Mexico. Comp Polit Stud. 2010;43(1):119-48. 
Pfutze, Tobias. The effects of migration on political clientelism in Mexico. Typescript. 2010.

Piper N. Temporary migration and political remittances: the role of organisational networks in the transnationalisation of human rights. Eur J East Asian Stud. 2009;8(2):215-43.

Portes A, Guarnizo LE, Landolt P. The study of transnationalism: pitfalls and promise of an emergent research field. Ethnic Racial Stud. 1999;22:217-37.

Przeworski A, Stokes S, Manin B, editors. Democracy, accountability, and representation. New York: Cambridge University Press; 1999.

Ratha D, Shaw W. South-south migration and remittances. Working paper no. 102. Washington: World Bank; 2007.

Schedler A. What is democratic consolidation? J Democr. 1998;9(2):91-107.

Shannon A. Las organizaciones transnacionales como agentes del desarrollo local. Retos y oportunidades del Programa $3 \times 1$ para Migrantes. In: de Castro RF, Zamora RG, Freyer AV, editors. El Programa $3 \times 1$ para migrantes: ¿primera política transnacional en México? México: ITAM, UAZ, Miguel Ángel Porrúa; 2006. p. 85-98.

Smith MP. Transnationalism, the state, and the extraterritorial citizen. Polit Soc. 2003;31(4):467-502.

Waldinger R. Between 'here' and 'there': immigrant cross-border activities and loyalties. Int Migr Rev. 2008;42:3-29.

Waldinger R, Popkin E, Aquiles Magana H. Conflict and contestation in the cross-border community: hometown associations reassessed. Ethnic Racial Stud. 2008;31(5):843-70.

World Bank. Global economic prospects: economic implications of remittances and migration. Washington: World Bank; 2006.

World Bank. Migration and remittances factbook. 2nd ed. Washington: World Bank Group; 2011.

Covadonga Meseguer Is a PhD in Political Science and a member of the Juan March Institute for Advanced Study in the Social Sciences (Madrid, Spain). Covadonga has been a Fulbright Fellow at New York University, Jean Monnet Fellow at the European University Institute (Florence), Visiting Fellow at the Helen Kellogg Institute for International Studies (University of Notre Dame), Visiting Professor at the Universitat Pompeu Fabra (Barcelona), Tereza Lozano Resource Visiting Fellow (University of Texas at Austin), and ICREA Visiting Professor at the Barcelona Institute for International Studies (IBEI). She writes on international migration, the internationalization of policies, and Latin American political economy. Her work has appeared or will appear in World Development, Latin American Politics and Society, Studies in Comparative International Development, European Journal of Political Research, Rationality and Society, European Journal of Political Economy, The Annals of the American Academy of Political and Social Science, Review of International Political Economy, Journal of Public Policy, and others. Her book manuscript "Learning, Policy Making, and Market Reforms" was published in 2009 by Cambridge University Press. She is currently an Associate Professor at the London School of Economics and at the Center for Research and Teaching in Economics (CIDE), Mexico City.

Katrina Burgess Is an Associate Professor of Political Economy at the Fletcher School at Tufts University. She is the author of Parties and Unions in the New Global Economy and co-editor with Abraham F. Lowenthal of The California-Mexico Connection. She has also published numerous book chapters and articles, including pieces in World Politics, South European Politics and Society, Comparative Political Studies, Politica y gobierno, International Studies Review, Studies in Comparative International Development, and Latin American Politics \& Society. Her current project addresses the impact of migration on politics in new democracies in the developing world. Professor Burgess received a B.A. in political science from Swarthmore College, an M.A. in international relations from the University of Southern California, and a Ph.D. in politics from Princeton University. She has also served as Assistant Director of the U.S.-Mexico Project at the Overseas Development Council in Washington, DC and Associate Director of the California-Mexico Project at USC in Los Angeles. 